NBSIR 76-1193

\title{
EARTHQUAKE RELATED ACTIVITIES OF THE CENTER FOR BUILDING TECHNOLOGY
}

Charles G. Culver

Center for Building Technology Institute for Applied Technology National Bureau of Standards

Washington, D. C. 20234

March 1977

U.S. DEPARTMENT OF COMMERCE, Juanita M. Kreps, Secretary

Dr. Betsy Ancker-Johnson, Assistant Secretary for Science and Technology NATIONAL BUREAU OF STANDARDS, Ernest Ambler, Acting Director 



\section{ABSTRACT}

This report describes activities related to earthquake engineering being carried out by the Center for Building Technology as part of the Center's overall Disaster Mitigation Program. Laboratory and field research, post disaster investigations and efforts to develop comprehensive earthquake resistant design provisions are included. The professional disciplines within the Center and the laboratory facilities are discussed. Recent accomplishments and mechanisms employed for facilitating implementation of the Center's research results are also discussed.

KEY WORDS : Buildings; design; disaster mitigation; earthquakes; engineering 



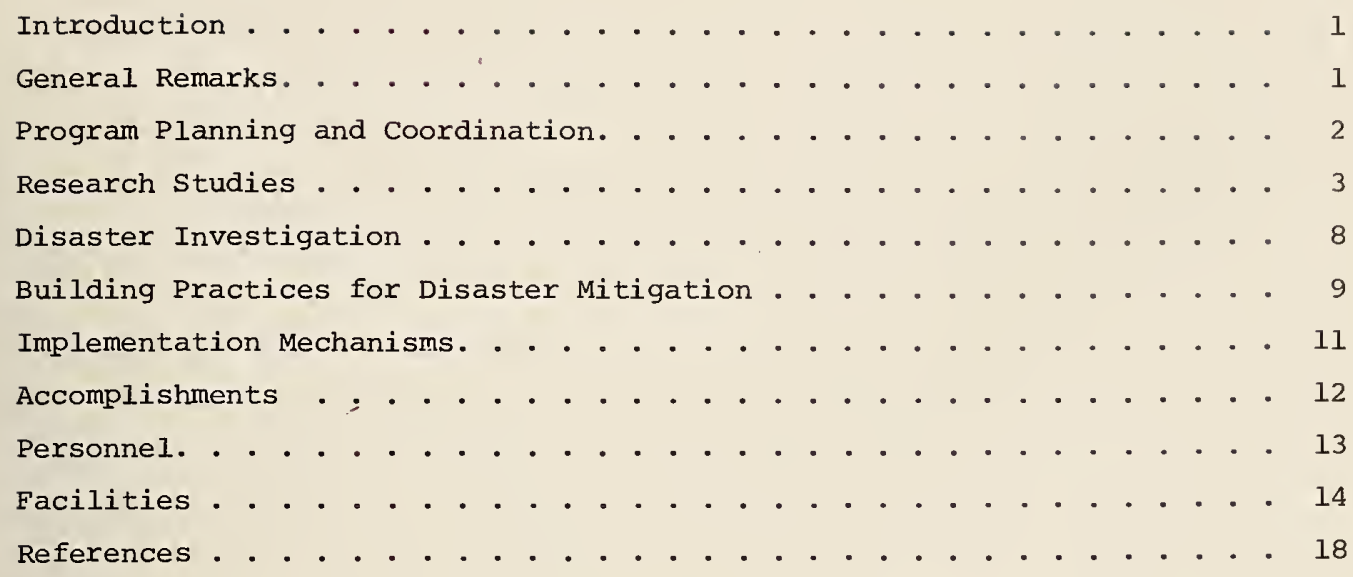





\section{INTRODUCTION}

The Disaster Mitigation Program at the National Bureau of Standards is under the direction of the Center for Building Technology (CBT). It focuses on the development of improved building practices to reduce damages caused by floods, hurricanes, tornadoes, earthquakes and other extreme natural forces. Major thrusts of this program include: 1) safety evaluation of existing buildings, 2) improved design criteria and standards, 3) post disaster investigations, and 4) more reliable measures of effects of natural forces on buildings.

Developing methods for assessing potential hazards in existing buildings prior to, or following, a natural disaster and for choosing cost-effective procedures to correct deficient building designs provides a means for reducing future loss of lives and property. Analytical and laboratory studies of the performance characteristics of building components provide information required to improve building design. On-site studies enable CBT scientists to validate lab findings and provide information on total building performance including assessment of architectural features, structural features, and mechanical and electrical systems. More reliable measures of the effects that natural forces have on buildings provide a rational basis for decisions on disaster mitigation.

This report provides a description of the earthquake related activities conducted under this program. These include: research, development, and implementation of improved building practices for reduction of earthquake hazards. These activities in earthquake engineering are coordinated with earthquake related efforts of other Federal agencies. They complement research funded by the National Science Foundation and utilize scientific knowledge from seismological studies of the U.S. Geological Survey.

\section{GENERAL REMARKS}

The objectives of earthquake related activities in the Center for Building Technology are to: (1) carry out needed research to fill gaps in existing knowledge, (2) facilitate incorporation of the results in standards, codes and professional practice. Efforts emphasize expressing building practices in "performance" terms applicable to all materials, components, or systems which may be employed. Consideration is given to the performance of the total bidilding in its total environment.

The basic authority for these activities is contained in the Organic Act of the National Bureau of Standards. These include: determination of properties of building materials and structural elements and encouragement of their standardization and most effective use; the development of methods for testing materials, mechanisms, and structures; cooperation with other governmental 
agencies and with private organizations in the establishment of standard practices, incorporated in codes and specifications; and advisory service to government agencies on scientific and technical problems. Efforts in each of these areas are discussed in subsequent sections of this report.

\section{PROGRAM PLANNING AND COORDINATION}

Since earthquakes could potentially cause great human suffering and property losses in all regions of the United States, there is a need for a balanced program of earthquake hazard reduction which includes earthquake risk assessment, mitigation and relief. CBT earthquake activities deal primarily with mitigation. In planning this work, close liaison is maintained with individuals and organizations in both the public and private sector. This insures coordination of CBT efforts with work carried out by other organizations.

CBT serves as a liaison member to the U.S. Geological Survey's Earthquake Studies Advisory Panel which examines earthquake prediction and other earthquake programs. CBT uses the USGS findings on seismic risk in its research and identifies for USGS the geological research needed by the building community.

Federal workshops on Building Science and Technology are held by NBS on a monthly basis. Several of these have considered the earthquake problem. They provide a forum for Federal agencies to discuss on-going work and to consider areas requiring additional study. CBT staff also regularly participate in the Federal Interagency Discussion Group on Disaster Mitigation established by the National Science Foundation.

In 1972, NBS and NSF conducted a special workshop providing a critical review of current building practices for disaster mitigation. Problems associated with earthquakes were included. Proceedings of the workshop (2)* included 15 review articles describing the state-of-the-art of building practices and recommendations for policy makers, best practices for current applications, improvements of building standards, and research needs.

CBT recently awarded a grant to the Earthquake Engineering Research Institute, a national professional organization devoted to the advancement of the science and practice of earthquake engineering, to conduct a workshop to develop a priority list of needed research in earthquake engineering. Discussions are underway with the three model code organizations (International Conference of Building Officials, Building Officials and Code Administrators, Southern Building Code Congress) to identify building problems associated with natural hazards from the perspective 
of building officials. CBT, with sponsorship by NSF, also conducted a workshop in september 1976 to examine the current state-of-the-art and identify research needs associated with earthquake resistant design of masonry structures.

The Center has established ties with research laboratories throughout the world. Affiliations with these groups range from joint-cooperative programs and information exchange to the sponsorship of various forums for the presentation of building research. NBS, for example, has responsibility for the U.S.-Japan Panel on Wind and Seismic Effects. This panel is one of the twenty panels in the U.S.-Japan Cooperative Program in Natural Resources establıshed in 1964 by the U.S.-Japan Cabinet-level Committee on Trade and Economic Affairs. Its purpose is to exchange technical information on the latest research and development activities within governmental agencies of both countries in the area of wind and seismic effects. Proceedings from workshops organized by this panel (12) provide a means for disseminating the latest research results to the professional community. CBT is involved in activities related to the $1974 \mathrm{Co}-$ operative agreement between the U.S. and the Soviet Union in the field of housing and other construction, participated in the UNESCO Intergovernmental Conference on the Assessment and Mitigation of Earthquake Risk in Paris in February, 1976 and the CENTO Conference on Recent Advances in Earthquake Hazard Minimization in Tehran in November 1976.

These interactions provide for the broad based input from design professionals, the research community, Federal agencies, building officials and regulatory groups required to identify and prioritize significant research problems in earthquake engineering.

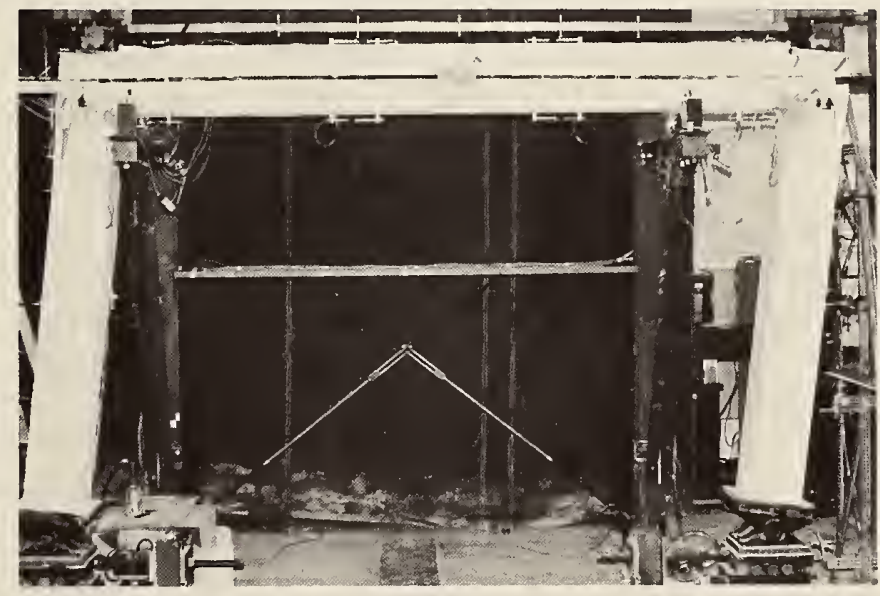

\section{RESEARCH STUDIES}

CBT research provides basic knowledge for the development of engineering standards and the measurements related to them. Projects related to earthquake engineering deal with the behavior of materials, individual components and systems subjected 
to earthquake loading. The center carried out a program, under sponsorship of the Defense Civil Preparedness Agency, to develop a methodology for survey and evaluation of existing buildings to determine risks of damage under natural disaster conditions and to identify how buildings can be strengthened if risks

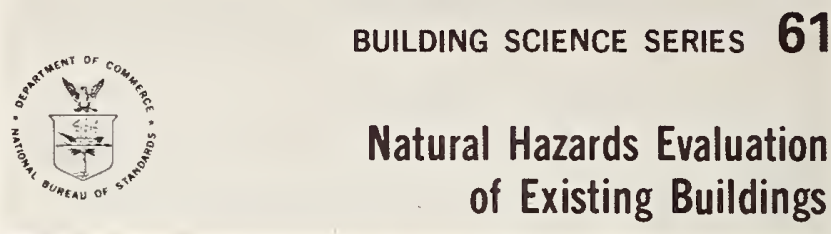

U.S. DEPARTMENT OF COMMERCE/National Bureau of Standards

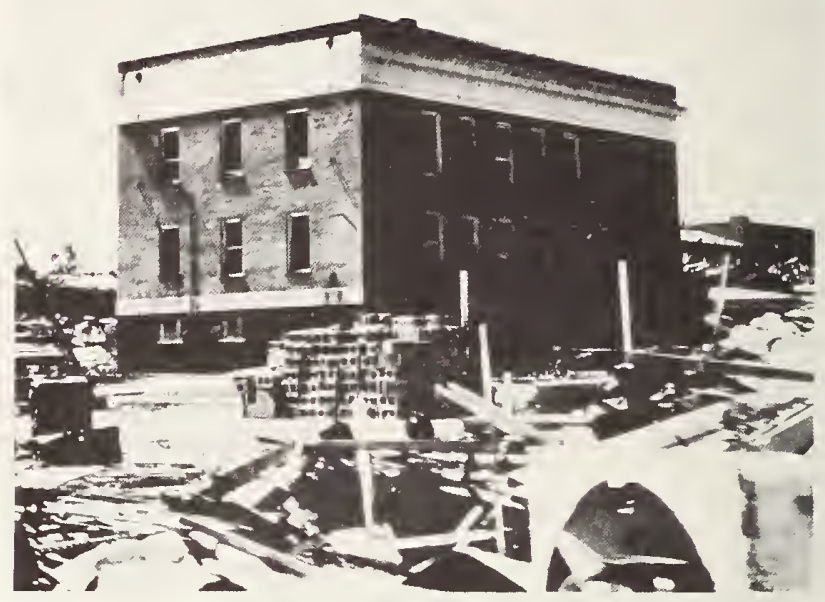

are excessive. (8). This was coordinated with the Defense Civil Preparedness Agency nuclear weapons effects survey. The program provided: definition of data to be collected in surveys to define natural disaster risks of existing buildings; procedures for evaluating building safety from the survey data; and criteria for defining "safe" buildings and those requiring strengthening or replacing. The criteria allow responsible authorities to define the safe level of risks in accord with local conditions including natural, economic, and social factors. Copies of the final report were forwarded to all regional directors of the Federal Disaster Assistance Administration at the request of FDAA headquarters in Washington. The General Services Administration has also used this research to develop surveys for evaluating buildings in response to Section 401 of P.L. 93-288, The Disaster Relief Act of 1974, which requires Federal agencies to evaluate the natural hazards to which their facilities are exposed and take appropriate action to mitigate these hazards. 


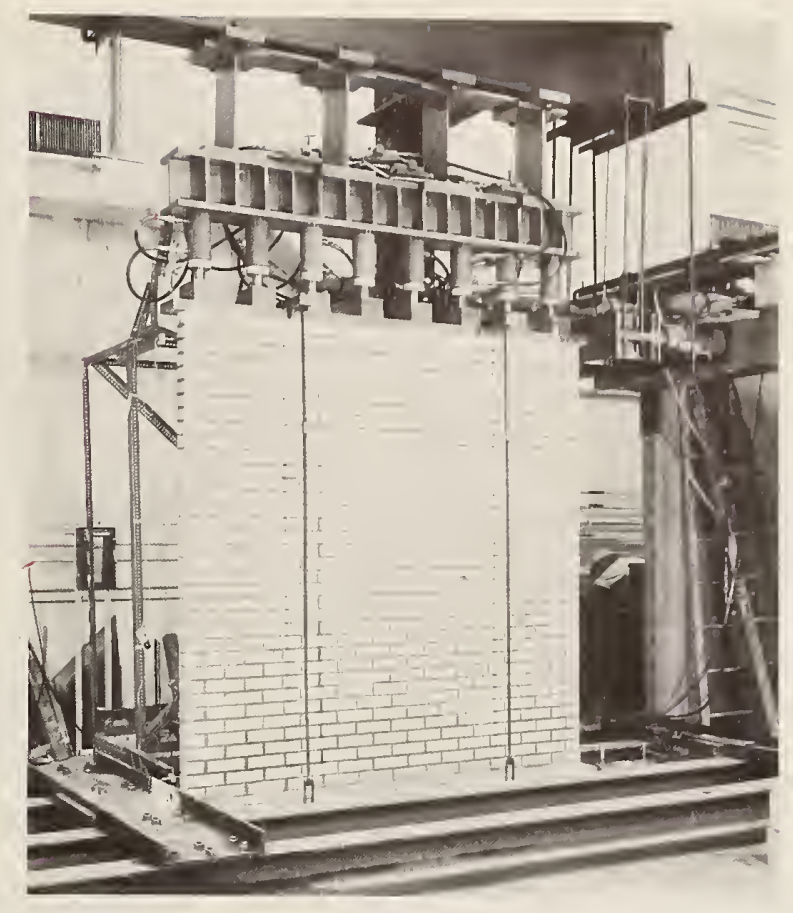

A cooperative program of research between industry and government has been established by the Center to improve the design of masonry structures in seismic regions. This project responds to the need for more information on the response of masonry structures to earthquake loads and is directed toward developing design criteria similar to those now used for steel and concrete construction. The project has three phases: Phase I: A study to compare existing standards, codes, and informal design practices with the state of the art, to compile test information, and to identify information that will require additional research. Phase II: A test program, designed to develop information on strength, stiffness, and ductility of shear-walls, to develop tests capable of measuring these properties, and to evaluate the performance of various design details. Phase III: The systhesis of results and development of design criteria. Research results from this work are included in a recent publication (13).

In a related project, an empirical design standard for masonry will be prepared under the American National Standards Institute, Inc. Standard A41.1. Compared with those of other construction materials, design standards for masonry are lagging. Because of industry fragmentation, there is also no overall consistent approach to masonry design encompassing brick, concrete block, composite construction, and other types of masonry. Besides the need for design standards for "engineered masonry," it is also necessary to preserve and revise the present empirical standard since the majority of masonry construction consists of projects for which the masonry is not designed by professional engineers. Damage to masonry construction recently observed in the Washington, DC area after a rather moderate storm underscores this need. 


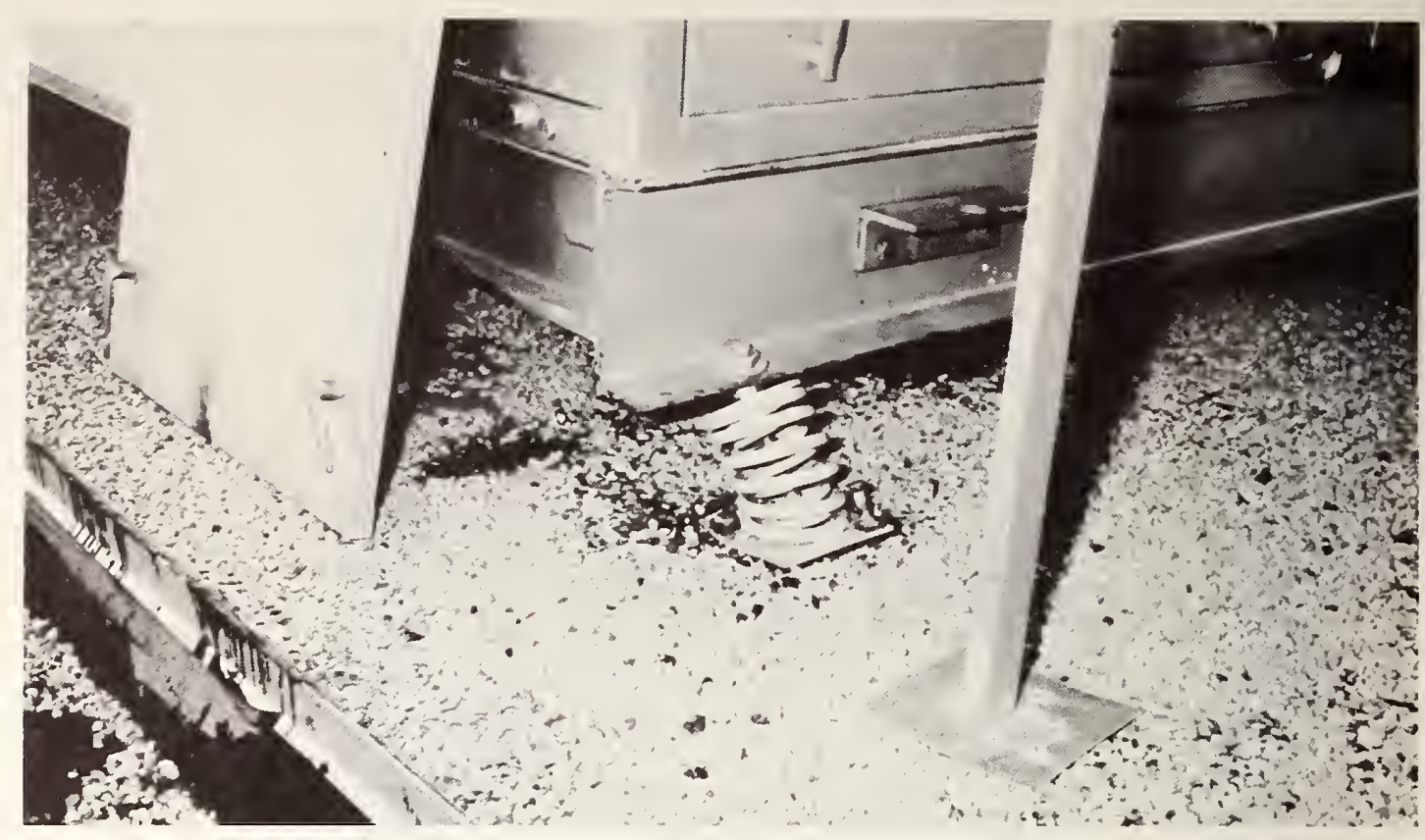

Another project developed a program plan for establishing seismic performance requirements for building service systems in critical facilities (hospitals, communication centers, etc.) that must remain functional following the occurrence of earthquakes. The earthquake-resistant design of service systems and the performance of these systems in past earthquakes was reviewed. Then a research plan was developed for obtaining information required to improve this seismic performance and to ensure functioning after an earthquake. The effort involved: (1) the identification of critical service systems and functional requirements for these systems following an earthquake; (2) a review of the nature and extent of building service system's damage resulting from earthquakes; and (3) a review of seismic design procedures for building service systems and the data used to establish these procedures. Critical service systems and user requirements for these systems following an earthquake were established by working directly with Federal agencies responsible for emergency facilities. The review of earthquake damage to service systems was carried out in consultation with individuals involved in post-disaster investigations. Particular attention was given to the limited data on failure modes for these systems and their performance following an earthquake. Needed experimental and analytical studies were identified and incorporated in an overall research plan for building service systems.

A project, under sponsorship of the Veterans Administration, was carried out to establish procedures for evaluation of the ultimate strength of unreinforced masonry walls in existing buildings to determine the seismic resistance of 
these buildings. The work included: compilation of existing test data defining the strength of typical types of masonxy, development of test methods (destructive and non-destructive) for determining strength and stiffness properties of walls, and recommendation of procedures for assigning strength values to walls and deriving the overall structural resistance as a function of wall resistance.

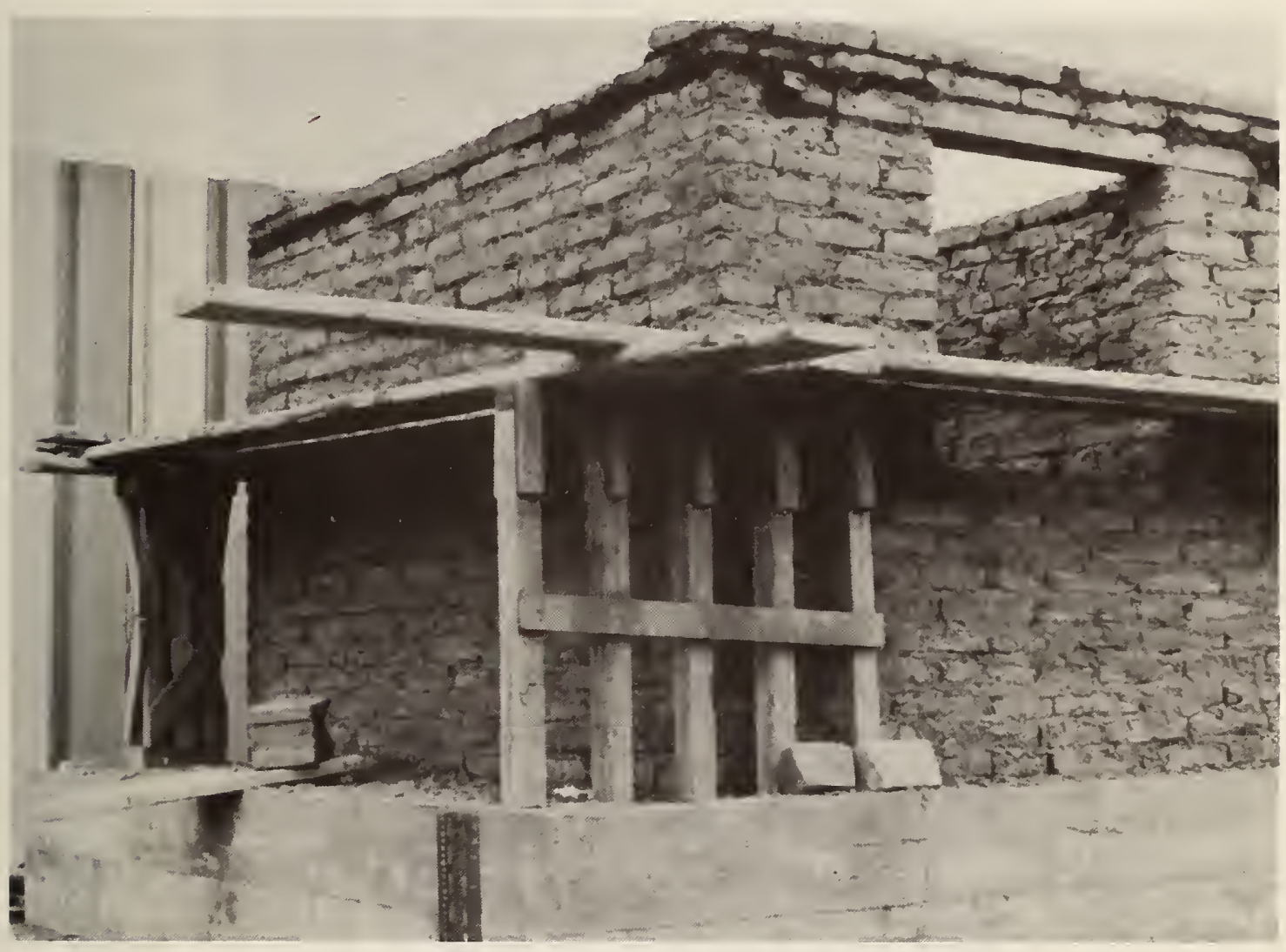

The Center conducted research to develop improved seismic design procedures for the use of indigenous construction materials used for shelters of low income occupancy in foreign countries. The project was carried out in Peru under an Agency for International Development Mission in Lima, Peru sponsored project. The project involved laboratory testing and the establishment of tentative criteria for stabilized cane reinforced adobe block construction. Prototype housing units were constructed in Peru based on the experimental work and NBS developed design calculations.

The Center also developed and implemented testing procedures for cyclic loading in connection with Operation BREAKTHROUGH. The procedures simulated the overturning effects of multi-story buildings encountered in earthquakes. 


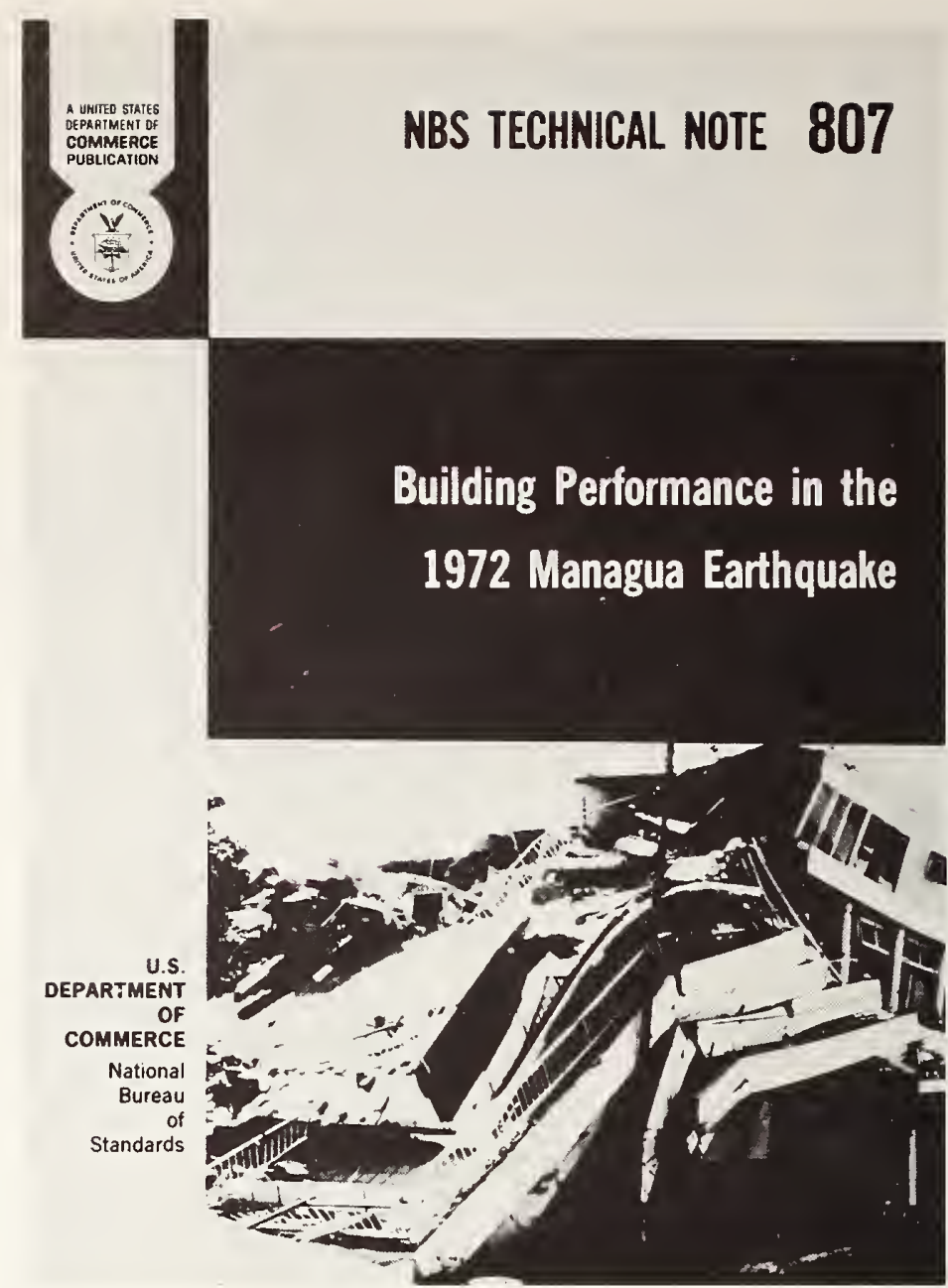

\section{DISASTER INVESTIGATIONS}

The Center for Building Technology has been extensively involved in disaster investigations. These activities evolved from ad hoc investigation teams supplied in response to requests from the Congress, the Defense Civil Preparedness Agency, the Office of Emergency Preparedness and the State Department. Through these investigations, CBT provides technical assistance in connection with relief and reconstruction efforts and acquires valuable field data on the performance of structures for use in developing improved building practices.

Post-disaster investigations were conducted following the earthquakes in: San Fernando, California in 1971 (1); Managua, Nicaragua in 1972 (3); and Guatemala and Italy in 1976. During the San Fernando investigation, CBT staff testified before the House Committee on Public Works at a field hearing in California on February 23, 1971 and discussed the damage to the San Fernando area. CBT also worked with the Small Business Administration to develop procedures for assessing earthquake damage for use in validating Federal loans. 
Following the Managua earthquake, CBT staff assisted Nicaraguan authorities in evaluating damaged buildings. A study of the Nicaraguan building regulatory system was carried out under the auspices of the organization of American States and the Agency for International Development. Recommendations were prepared on the status and development of this system and its technical bases (10). The Guatemala earthquake provided an opportunity to assess the performance of buildings designed on a similar basis to buildings in California. Following the earthquake in Italy in May 1976 CBT provided technical assistance to the Agency for International Development in assessing the structural damage in the earthquake area and the structural engineering aspects of reconstruction. CBT staff participated on the AID team established to work with the Italian government in connection with U.S. financial assistance to the disaster victims.

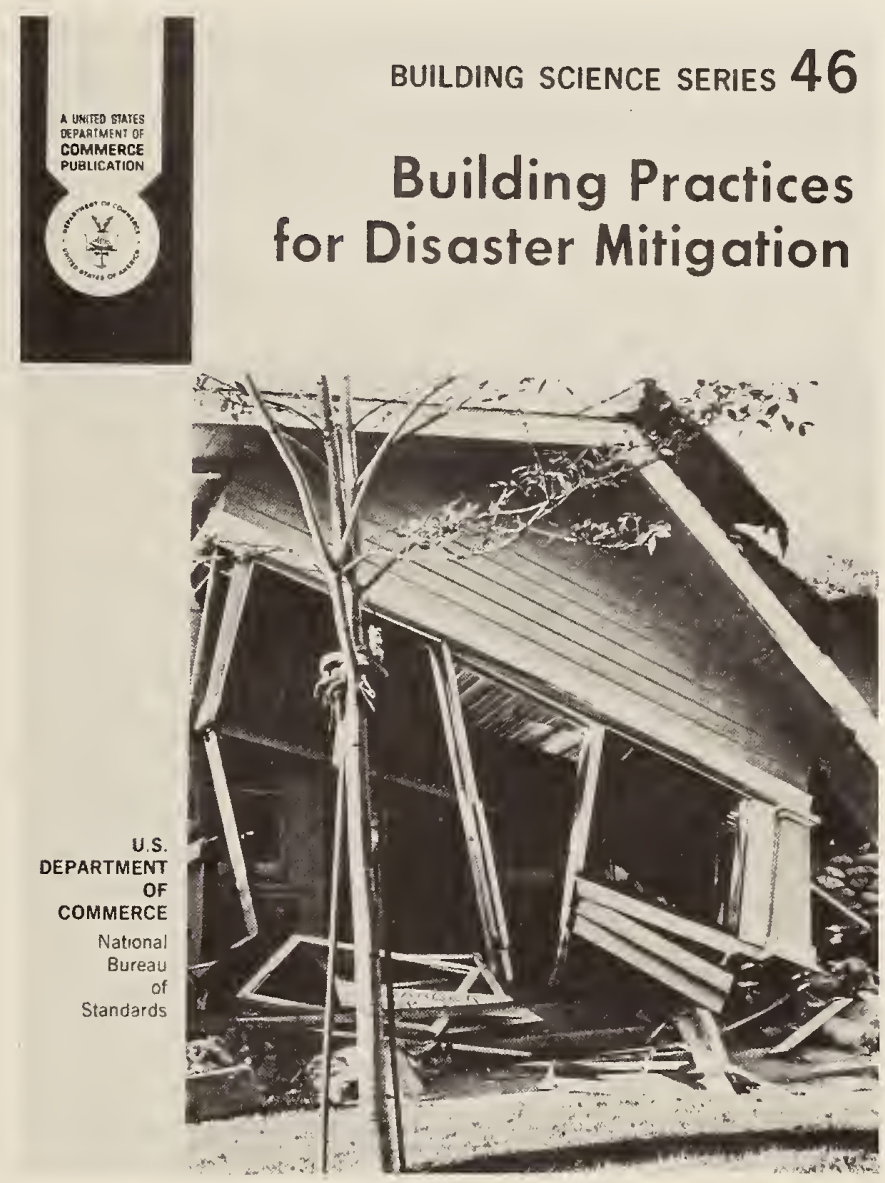

\section{BUILDING PRACTICES FOR DISASTER MITIGATION}

The National Science Foundation (NSF), NBS, Department of Housing and Urban Development (HUD), and OEP planned a cooperative Federal program on building practices for disaster mitigation in 1972. With sponsorship from NSF, the NBS conducted a workshop for experts in the building community including architects and engineers, building code officials, standards writers, and 
planners, to develop a national plan for disaster mitigation activities. The workshop participants systhesized current knowledge on building practices for insuring the safety of building occupants in new and existing buildings. They made recommendations to four audiences: 1) policy makers in Federal, State and local governments, for guidance on disaster mitigation laws, regulations, policies, and programs; 2) practitioners, such as architects, engineers, and building contractors, for guidance on the best current practices to be used in making decisions about building construction; 3) standards writers and those responsible for developing recommended practices, such as building code officials, for guidance on the deficiencies in present practices; and 4) researchers, for guidance on needs for new knowledge. This plan and the proposed recommendations to users in the building community (2) provided an integrated approach to disaster mitigation through research and the implementation of improved building practices.

One workshop recommendation was to update the seismic provisions of building codes. The last major revision to these provisions occurred in the 1950's. Since that time, there have been significant advances in knowledge. Based on the workshop recommendation, the National Bureau of Standards and the National Science Foundation initiated a three-year $\$ 1.3$ million program to develop improved seismic design criteria which could be used nationwide in new buildings and in the rehabilitation of existing buildings. The Applied Technology Council, an organization which serves as the research arm for the Structural Engineers Association of California, is acting as a principal resource.

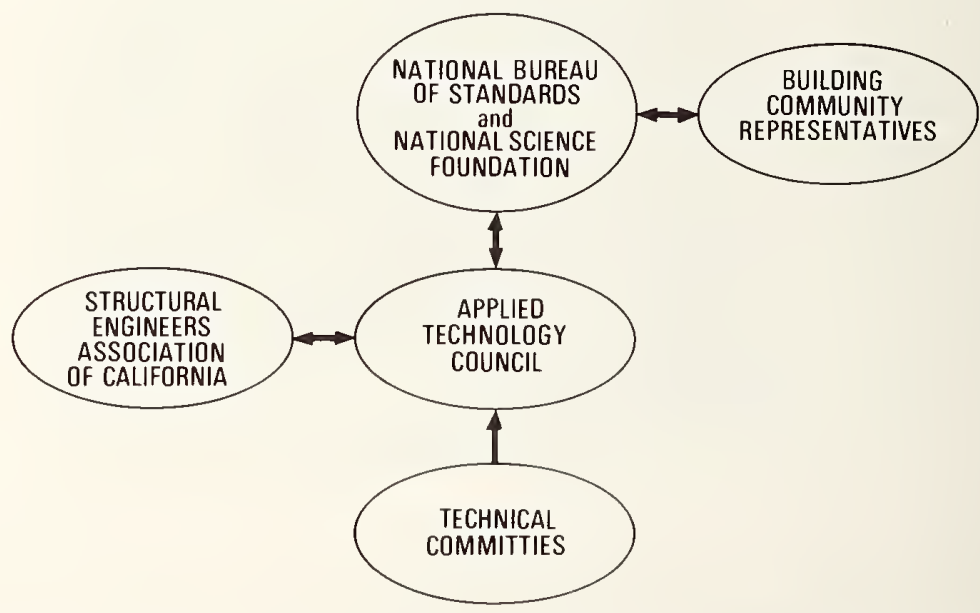

Eighty experts from throughout the United States representing all sectors of the building community are participating in the development of the design criteria. In selecting these experts, NBS chose people from all areas of the country, with strong participation by representatives from California and other 
high seismic risk areas to insure consideration of various localities' needs and effective implementation. Current seismic provisions are based on California seismic conditions and building practices. The nationwide representation in development of the new criteria assures consideration of all types of construction and degrees of seismic risk. This nationwide involvement of building regulatory officials and designers will promote more rapid adoption in state and local building codes.

The new seismic design criteria differ in scope from past code provisions, since they include non-structural, as well as structural, aspects of the building. During earthquakes, many people are killed or seriously injured from improper designs of such non-structural elements as bookcases, internal partitions, and light fixtures. The inclusion of these nonstructural elements makes the proposed design criteria much more comprehensive. Guidelines providing a scientific basis for the formulation and expression of performance standards and specifications (14) developed by СВT are being used in preparing these design criteria.

\section{NATIONAL BUREAU OF STANDARDS}

\section{SERVES:}

- DESIGN PROFESSION

- INDUSTRY

- LABOR

- tHe PUBLIC

- federal AGencies

- STATE \& local goVERNMENTS

\section{THROUGH BUILDING RESEARCH AND TECHNICAL SERVICES}

\section{IMPLEMENTATION MECHANISMS}

To insure appropriate implementation of the Center's research results, CBT works closely with all elements of the building community: design professionals, builders, organized labor, building regulatory authorities of state and local governments, researchers in universities, national standards writing bodies, 
building user organizations, and Federal agencies. The noted interactions on program planning and coordination insure a broad based input in establishing research priorities and facilitates incorporation of the results in professional practice and standards and codes. The Federal workshops provide for dissemination to professionals in the Federal agencies. Interagency agreements, such as a Secretary to Secretary agreement with the Department of Housing and Urban Development providing for technical support of HUD activities including the review and revisions of the FHA Minimum Property Standards and sponsorship of CBT research by Federal agencies, provide the means for including research results in Federal standards.

Working through the National Conference of States on Building Codes and Standards, an organization composed of representatives from the 50 states working toward state-wide updated building regulatory systems, the Center provides liaison with State and local governments and specification writing and regulatory agencies. Meetings are also held with the technical directors of the three model codes to inform them of the latest CBT' research. Staff from the Center serve on over 190 professional committees and organizations concerned with the development of consensus standards. The Center provides the secretariat for the American National Standards Institute Committee A58 concerned with design loads for buildings. This provides a vehicle for transferring the seismic design provisions, as well as other CBT research, directly to nationally accepted consensus standards organizations.

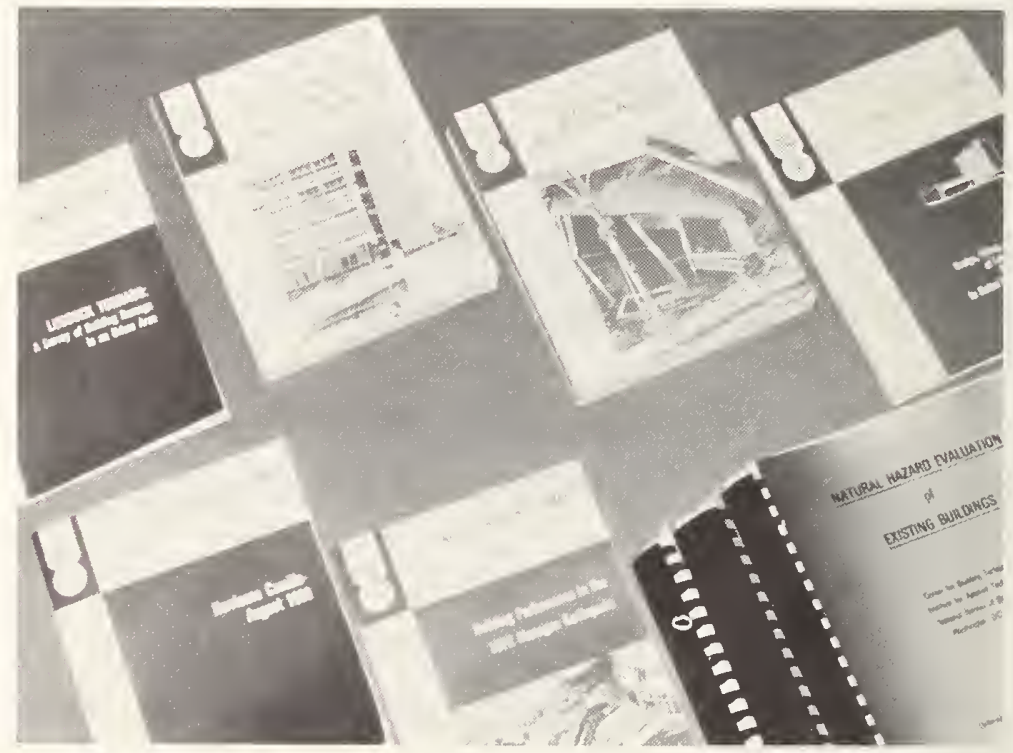

\section{ACCOMPLISHMENTS}

CBT research results are disseminated to the building community through NBS technical reports, presentations at professional meetings and through direct contact with staff from the various organizations. A list of reports dealing 
with earthquake research is included in section 11. Requests from throughout the world have been received for these reports.

The initial draft of the seismic design provisions developed in the Building Practices Program has been reviewed by over 400 professionals, trade associations and regulatory officials. The model code groups, Federal agencies and other regulatory groups have indicated an intent to consider the final recommendations for inclusion in their regulations. The ANSI A58 committee is planning to establish a special subcommittee for this purpose.

The procedures developed by CBT for measuring the strength of masonry walls in existing buildings have been included in the Veterans Administration's "Earthquake Resistant Design Requirements for VA Hospital Facilities". Evaluations of VA hospitals in seismic zones 2 and 3 are required to be carried out in accordance with these procedures. Following the earthquakes in Guatemala in February 1976, Peruvian officials recommended that the results obtained by CBT for reinforcing adobe structures to better withstand earthquakes be considered in reconstructing destroyed homes.

Center for

4 uilding lechnology

\section{DISCIPLINES OF CBT STAFF}

- Architecture

- Architectural Engineering

- Behavioral Psychology

- Bioacoustics

- Building Codes

- Ceramic Engineering

- Chemical Engineering

- Chemistry

- Civil Engineering

- Communications

- Cost Engineering
- Economics

- Electronics Engineering

- Environmental Engineering

- General Engineering

- Geology

- Housing Technology

- Hydraulic Engineering

- Industrial Engineering

- Materials Engineering

- Mathematics

- Mechanical Engineering
- Metallurgy

- Operations Research

- Physics

- Psychology

- Public Administration

- Safety Engineering

- Sanitary Engineering

- Sociology

- Structural Engineering

- Urban Planning

\section{PERSONNEL}

At the Center, research is carried out in three laboratory-based divisions:

- Structures, Materials \& Safety

- Building Environment

- Technical Evaluation \& Application

In addition, two offices manage interdisciplinary teams tackling complex 
problems, provide technical inputs to the states and local government, and provide client liaison:
- Building Codes \& Standards
o Housing \& Building Technology.

The staff includes engineers, architects, physical scientists, economists, psychologists and other specialists from over 30 disciplines. The competence and experience of the center for Building Technology in building research and in the implementation of improved building practices permit substantial contributions to Federal programs in earthquake engineering. CBT earthquake research draws from such disciplines as: structures, interior environments, durability of materials, fire safety, standards and codes, architecture, building economics, and the thermal and sensory environments. This interdisciplinary approach considers how buildings should perform to meet building occupants' needs.

\section{FACILITIES}

A variety of special facilities and equipment are available at the National Bureau of Standards (9). Some of this equipment is unique and not available elsewhere. The most actively involved facilities engaged in earthquake research are the laboratories of the Structures Section of the Center for Building Technology.

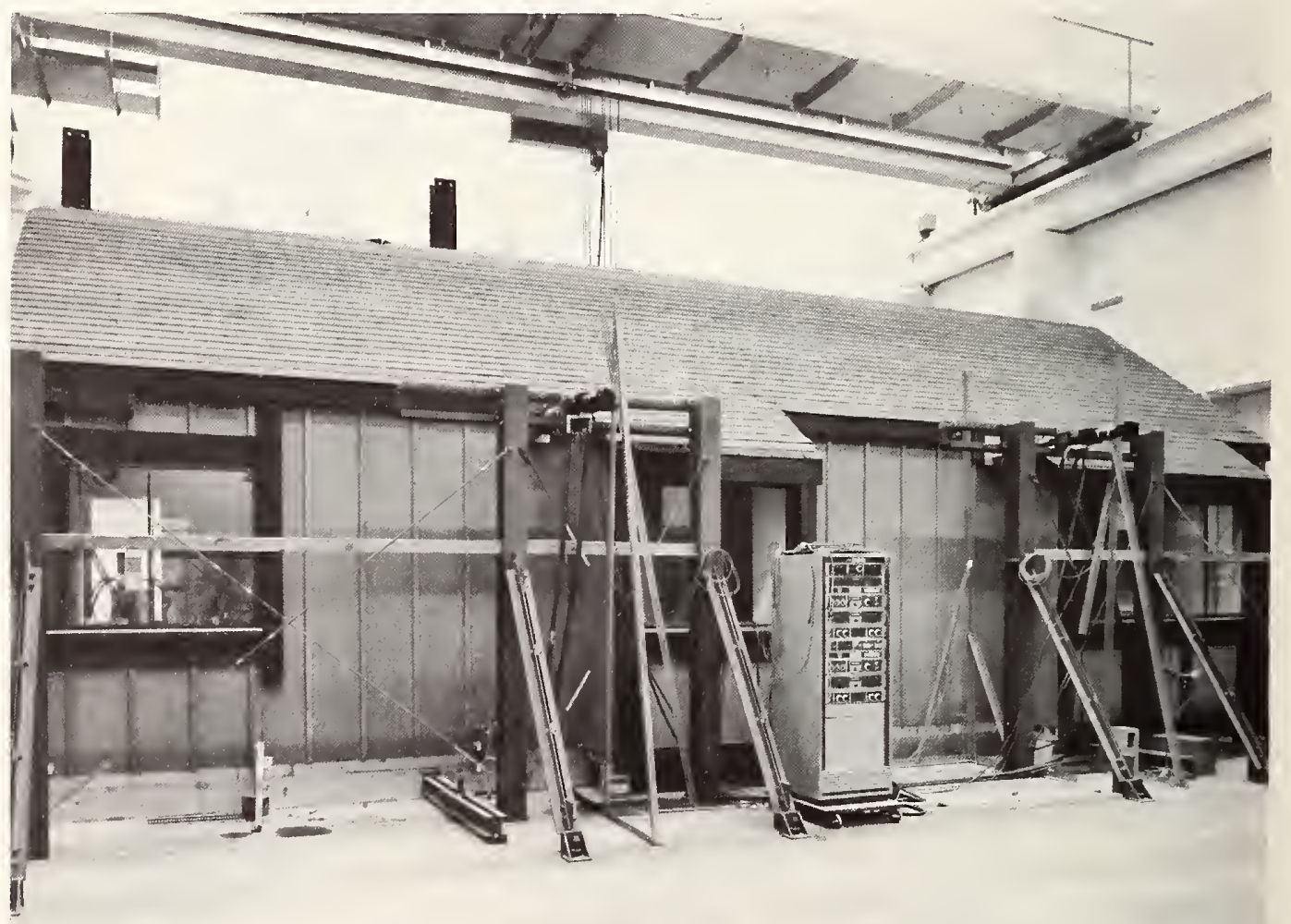


Static and dynamic testing is accomplished by use of a heavily reinforced tie-down floor permitting mounting of complete structural members. Hydraulic actuators provide test loads in dynamic tests. Automatic recording of up to 200 channels of sensor data is accomplished by a mini-computer-controlled data acquisition system.

The main test floor of heavily reinforced concrete and imbedded I-beam is $53 \times 47$ feet $(16 \times 14 \mathrm{~m})$ in size and is supplemented in the long direction by a 25 foot $(7.6 \mathrm{~m})$ extension, 20 feet $(6.1 \mathrm{~m})$ wide, for testing long beams. The 53-foot $(16 \mathrm{~m})$ section has a $12,000 \mathrm{kip}-\mathrm{ft}(16,260 \mathrm{kN} . \mathrm{m})$ bending moment capacity, and its 25 -foot $(7.6 \mathrm{~m})$, extension has a bending moment capacity of $8,000 \mathrm{kip}-\mathrm{ft}$ $(10,840 \mathrm{kN} . \mathrm{m})$. The crosswise section 47 feet $(14 \mathrm{~m})$ in length will withstand a total bending moment of $21,000 \mathrm{kip}-\mathrm{ft}(28,455 \mathrm{kN} . \mathrm{m})$. The floor will withstand a total horizontal shear force of $1800 \mathrm{kips}(8010 \mathrm{kN})$ in either direction and a vertical shear force of $2,000 \mathrm{kips}(8900 \mathrm{kN})$. It is serviced by two 10-ton $(4530 \mathrm{~kg}$ ) bridge cranes having a clear hook height of 25 feet $(7.6 \mathrm{~m})$. The ninety-nine anchorage tie-down points are designed to withstand $100 \mathrm{kips}$ (445 kN) of either tension force or horizontal shear force. Six additional points have twice this capacity. Within this laboratory, full-sized buildings are utilized for research projects and are subjected to structural testing and evaluations, such as the Navy Lewis Building, the Neal Mitchell housing systems, and the Levitt House from Operation BREAKTHROUGH. An associated laboratory, 22 x 75 feet, $6.7 \times 22.9 \mathrm{~m})$ is serviced by two 2-ton $(1814 \mathrm{~kg}$ ) cranes and contains two universal testing machines of 60,000-lbs, (267 kN), one of 200,000-lbs (890 kN) capacity, and two compression machines of 300,000-lbs (1335 kN) and 600,000-lbs (2670 kN) capacity. The $600,000-1 \mathrm{~b}(2670 \mathrm{kN})$ capacity machine has adequate clearance for testing an 8 -ft high $(2.4 \mathrm{~m}), 4-\mathrm{ft}(1.2 \mathrm{~m})$ wide structural member.

Beams, slabs, frames or complete structures can be subjected to static loads as limited by test floor capacity or cyclic loads up to 50,000 pounds (222.5 kN) with programmed amplitude and frequency. Signals in the range of 0 to 300 volts from load cells, strain gages, pressure transducers, LVDT's, and other types of electromechanical sensors are recorded on magnetic tape and optionally printed on teletypewriters. Two mini-computer controlled data acquisition systems are available. A 200-channel portable system for either laboratory or field use provides digital recording under manual or computer control. Another 112 channels of data may be recorded in digital form by a laboratory-based system. Its channels may be accessed in sequence or at random while under computer control, and manual control is also available. Any 14 of these 112 channels may be used for recording in analog form on magnetic tape.

Software packages are available for processing data obtained by either of these systems on the central NBS computer. Processing may be controlled through the 
- use of a laboratory-located remote terminal.

A hydraulically operated universal testing machine of 12-million pounds-force $(53,400 \mathrm{kN})$ capacity, believed to be the largest in the world, designed to test large structural components and to apply the forces needed to calibrate force measuring devices of large capacity is also available.

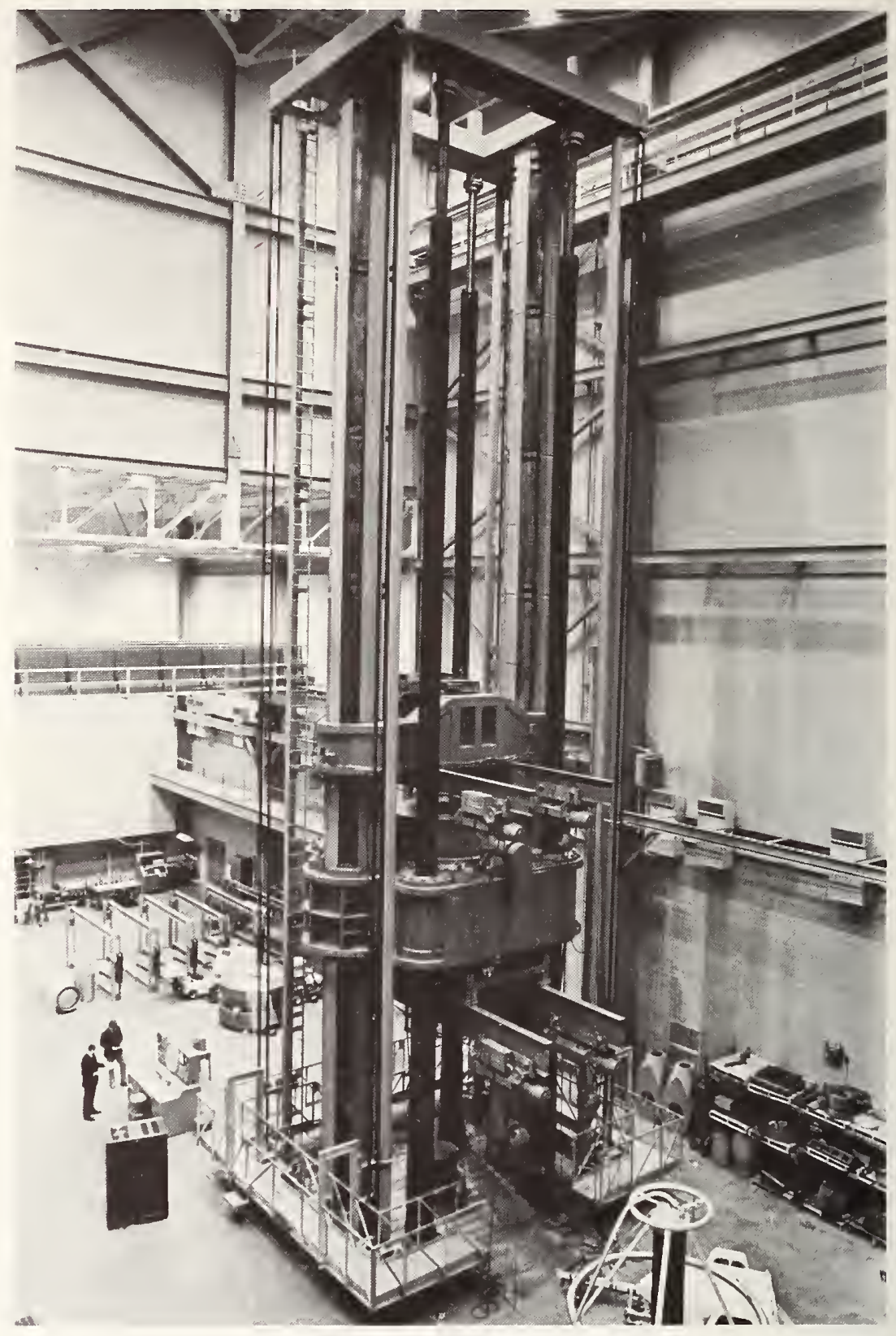

The machine can apply axial force of $12,000,000$ lbf $(53,400 \mathrm{kN})$ in compression $6,000,000 \mathrm{lbf}(26,700 \mathrm{kN})$ in tension, and a transverse force of $4,000,000 \mathrm{lbf}$ $(17,800 \mathrm{kN})$ to a flexural member. Working space between the screw columns is 8 feet 4 inches $(2.5 \mathrm{~m})$, and the working surface of the main platen is 8 feet 4 inches $(2.5 \mathrm{~m})$ by 15 feet $(4.6 \mathrm{~m})$. The reinforced concrete foundation includes 
a tie-down floor system with the following working strength values:

Longitudinal bending moment

(over central 40 feet, 12m)

Transverse bending moment

(over central 40 feet; $12 \mathrm{~m}$ )

Uniform bearing

Tensile force on anchor bolts

$$
\begin{aligned}
& 12,500 \mathrm{kip}-\mathrm{ft}(16,938 \mathrm{kN} . \mathrm{m}) \\
& 20,000 \mathrm{kip}-\mathrm{ft}(27,100 \mathrm{k} \mathrm{N} \cdot \mathrm{m}) \\
& 467 \mathrm{kip}-\mathrm{ft} / \mathrm{ft}(193 \mathrm{kN} \cdot \mathrm{m} / \mathrm{m}) \text { of width } \\
& 750 \mathrm{kip}-\mathrm{ft} / \mathrm{ft}(310 \mathrm{kN} \cdot \mathrm{m} / \mathrm{m}) \text { of width } \\
& 940 \mathrm{lbf} / \mathrm{in} 2(6486 \mathrm{kN} / \mathrm{m}) \\
& 150,000 \mathrm{lbf} / \mathrm{bolt}(667.5 \mathrm{kN} / \mathrm{bolt})
\end{aligned}
$$

There are two hydraulic capsules in the sensitive crosshead, one providing the force measuring function and the other for preloading. Pressure transducers in a constant temperature oven on the crosshead provide signals to analog readout for force, strain, and displacement, and also to a digital readout calibrated to within \pm 0.5 percent of the applied load. Both coarse and fine adjustment of power cylinder motion $[5$ feet $(1.5 \mathrm{~m})$ max. $]$ are provided from the control console.

Axial forces of $12,000,000 \mathrm{lbf}(53,400 \mathrm{kN})$ can be applied to column sections or fabricated members with lengths up to 58 feet $(17.7 \mathrm{~m})$, or to elastic devices such as the load cells used to measure rocket thrust or folling mill forces. To apply the full 6,000,000 lbf $(26,700 \mathrm{kN})$ tension to eye bars, drill rod for undersea operations, large diameter wire rope, and the like, both threaded couplings and clevis fixtures are provided to take specimens up to 53 feet $(16.2 \mathrm{~m})$ long. Transverse or flexural tests under 4,000,000 lbf $(17,800 \mathrm{kN})$ load can be made on beams and similar structures with lengths up to 90 feet $(27.5 \mathrm{~m})$.

Other facilities include a field testing capability employing a specially designed van for transporting and field support of loading, instrumentation and data acquisition systems. 
11. REFERENCES

1. Lew, H.S., Leyendecker, E.V., Dikkers, R.D., "Engineering Aspects of the 1971 San Fernando Earthquake", Building Science Series 40, National Bureau of Standards, Washington, DC, December 1971.

2. Wright, Richard; Kramer, Samuel; Culver, Charles; Editors, "Building Practices for Disaster Mitigation", Building Science Series 46, National Bureau of Standards, Washington, DC, February 1973.

3. Wright, R.N., Kramer, S., "Building Performance in 1972 Managua Earthquake", NBS Technical Note 807, National Bureau of Standards, Washington, DC, November, 1973.

4. Reps, W.F., Simiu, E., "Design, Siting, and Construction of Low-Cost Housing and Community Buildings to Better withstand Earthquakes and Windstorms", Building Science Series 48, National Bureau of Standards, Washington, DC, Januarỳ 1974.

5. Sav, G. T., "Natural Disasters: Some Empirical and Economic Considerations", NBSIR 74-473, National Bureaú of Standards, washington, DC, February, 1974.

6. Fattal, S.G., Cattaneo, L.E., "Evaluation of Structural Properties of Masonry in Existing Buildings", NBSIR 74-520, National Bureau of Standards, Washington, DC, July 1974.

7. Applied Technology Council, San Francisco, California, "An Evaluation of a Response Spectrum Approach to Seismic Design of Buildings", ATC-2, National Science Foundation and National Bureau of Standards, September, 1974 .

8. Culver, C., Lew, H.S., Hart, G.C., Pinkham, C.W., "Natural Hazards Evaluation of Existing Buildings", Building Science Series 61 , National Bureau of Standards, Washington, DC, January 1975.

9. Mason, H.L., Lloyd, I.M., "Special Technical Facilities at the National Bureau of Standards", NBS Special Publication 413, National Bureau of Standards, Washington, D.C., January 1975.

10. Wright, Richard N., Lamana, Atilano, "A Technical Review of the Nicaraguan Building Regulatory System" Technical Note 885, National Bureau of Standards, Washington, D.C., October 1975. 
11. Applied Technology Council, San Francisco, California, "Working Draft of Recommended Comprehensive Seismic Design Provisions for Buildings", ATC-3-04, National Science Foundation and National Bureau of Standards, January 1976.

12. Lew, H.S., Editor "Wind and Seismic Effects", Proceedings of the Sixth Joint Panel Conference of the U.S.-Japan Cooperative Program in Natural Resources, Special Publication 444, National Bureau of Standards, Washington, D.C., April 1976.

13. Fattal, S.G., Cattaneo, L.E., "Structural Performance of Masonry Walls Under Compression and Flexure", Building Science Series 73, National Bureau of Standards, Washington, DC, June 1976.

14. Fenves, Steven J., Rankin, Kirk, Tejuja, Hotchand K., "The Structure of Building Specifications", Building Science Series 90, National Bureau of Standards, Washington, D.C., September 1976. 
NBS-114A (REV. 7-73)

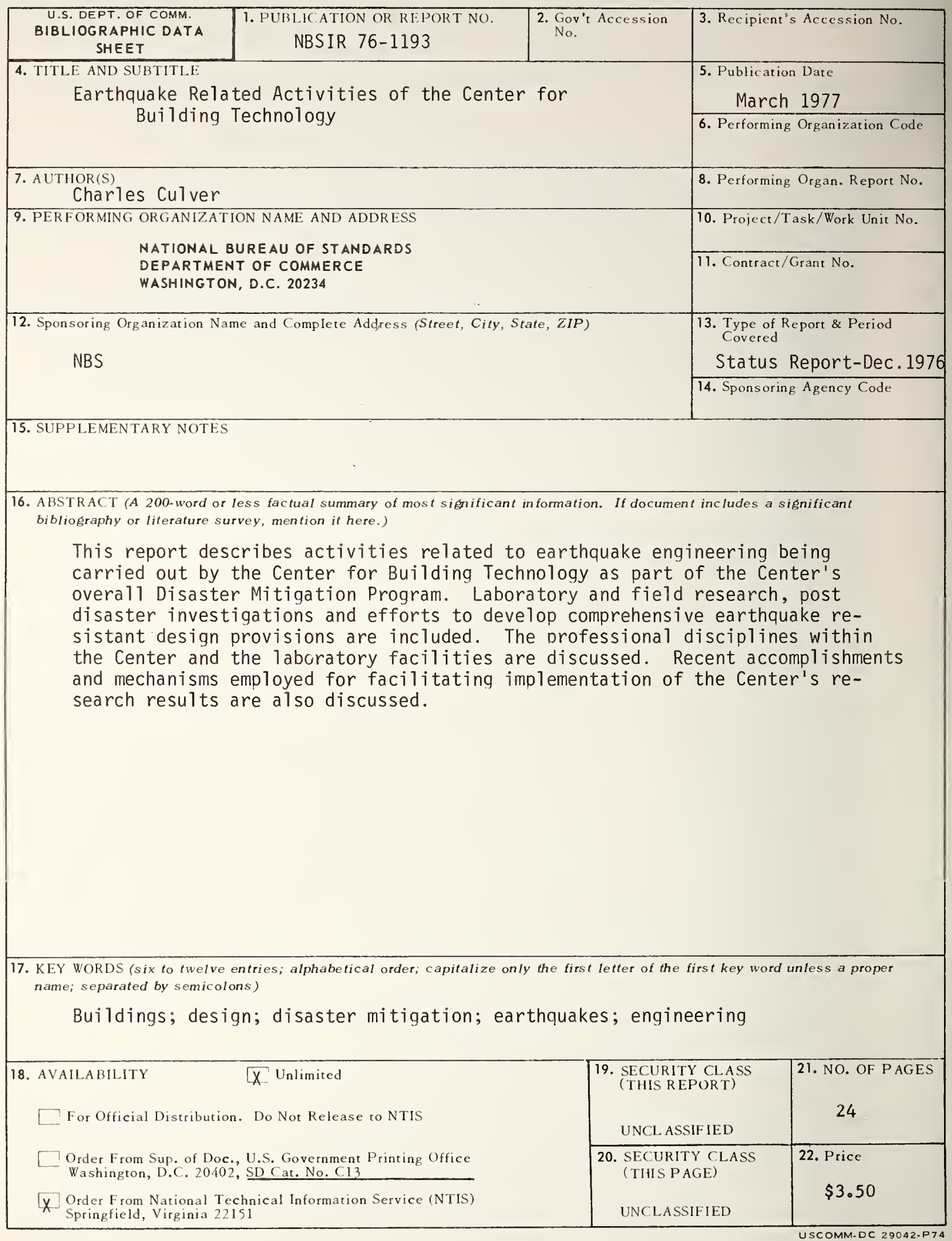

